\title{
Comparative analysis of the phytochemical and antibacterial activity of the root extracts of Euphorbia heterophylla and Vitellaria paradoxa
}

\author{
*Oyedum, U. M., Kuta, F. A., Garba, S. A., and Enejiyon, S. O. \\ Department of Microbiology, School of Life Sciences, Federal University of Technology, Minna, Nigeria \\ *Correspondence to: hemdi41@gmail.com
}

\begin{abstract}
:
Background: Over time, herbal plants and their various components have been major sources of therapeutic medicine for man. A comparative study was carried out to determine the phytochemical components and antibacterial activities of the different crude extracts of Euphorbia heterophylla and Vitellaria paradoxa roots on four enteric bacteria; Salmonella typhi, Shigella flexneri, Escherichia coli and Proteus vulgaris.

Methodology: Root samples of E. heterophylla and V. paradoxa were collected, washed, air dried and processed to fine powder in the microbiology laboratory of Federal University of Technology, Minna, Nigeria. Crude extract of the root samples was done by the cold maceration technique using four solvents (chloroform, methanol, petroleum ether and water). Phytochemical analysis of the extracts was done using previously described technique, and in vitro antibacterial activities of different concentrations of the extracts $(50-200 \mathrm{mg} / \mathrm{ml})$ and a standard antibiotic (ciprofloxacin) were tested on four enteric bacteria (S. typhi, S. flexneri, E. coli, P. vulgaris) by the agar diffusion test. In vivo antibacterial activities of the two plants were also tested by daily oral administration of $2000 \mathrm{mg} / \mathrm{kg}$ bodyweight (for 7 days) of each extract on inbred mice infected through intraperitoneal inoculation of an infective dose of each of the four enteric bacteria. Data were computed as mean \pm standard error and analysed by the Statistical Analysis System (SAS) version 9.4. Associations between variables were determined using analysis of variance (ANOVA), with $p<0.05$ considered as significant value.

Results: Phytochemical analysis of the crude extracts of both plants revealed the presence of cardiac glycosides, saponins, alkaloids, flavonoids, and tannins but $V$. paradoxa contain more carbohydrates and starch, and less phlobatannins, compared to $E$. heterophylla. In vitro assay showed dose-dependent antibacterial activity of the methanol, aqueous and chloroform (but not petroleum ether) extracts of the two plant roots. The in vitro antibacterial activities of the different extracts of $V$. paradoxica extracts were significantly higher (higher mean diameters of inhibition zones) than those of $E$. heterophylla $(p<0.05)$, and methanol extracts gave the highest antibacterial effects. However, the root extract of $E$. heterophylla gave a higher antibacterial activity with the in vivo assay on inbred mice than $V$. paradoxa, and methanol extracts of the two plant extracts gave the highest in vivo activity, followed by aqueous extract and least activity was obtained with the chloroform extract.

Conclusion: Crude extracts of $E$. heterophylla and $V$. paradoxa roots produce antibacterial activity against enteric Gram-negative bacteria pathogens involved in diarrhoea illnesses. Further researches should be directed towards isolation and characterization of the active compounds in the crude extracts.
\end{abstract}

Keywords: Roots; Phytochemicals; In vitro; In vivo; Euphorbia heterophylla; Vitellaria paradoxa; Enteric bacteria

Received Jan 3, 2021; Revised Aug 15, 2021; Accepted Aug 17, 2021

Copyright 2021 AJCEM Open Access. This article is licensed and distributed under the terms of the Creative Commons Attrition 4.0 International License $<$ a rel="license" href="http://creativecommons.org/licenses/by/4.0/", which permits unrestricted use, distribution and reproduction in any medium, provided credit is given to the original author(s) and the source. Editor-in-Chief: Prof. S. S. Taiwo

\section{Analyse comparative de l'activité phytochimique et antibactérienne des extraits de racines d'Euphorbia heterophylla et de Vitellaria paradoxa}

\author{
*Oyedum, U. M., Kuta, F. A., Garba, S. A., et Enejiyon, S. O.
}


Département de microbiologie, École des sciences de la vie, Université fédérale de technologie, Minna, Nigéria *Correspondance à: hemdi41@gmail.com

\section{Abstrait:}

Contexte: Au fil du temps, les plantes médicinales et leurs divers composants ont été une source majeure de médecine thérapeutique pour l'homme. Une étude comparative a été réalisée pour déterminer les composants phytochimiques et les activités antibactériennes des différents extraits bruts de racines d'Euphorbia heterophylla et de Vitellaria paradoxa sur quatre bactéries entériques; Salmonella typhi, Shigella flexneri, Escherichia coli et Proteus vulgaris.

Méthodologie: Des échantillons de racines d'E. heterophylla et de $V$. paradoxa ont été collectés, lavés, séchés à l'air et transformés en poudre fine dans le laboratoire de microbiologie de I'Université fédérale de technologie, Minna, Nigéria. L'extraction brute des échantillons de racines a été réalisée par la technique de macération à froid en utilisant quatre solvants (chloroforme, méthanol, éther de pétrole et eau). L'analyse phytochimique des extraits a été effectuée en utilisant la technique décrite précédemment, et les activités antibactériennes in vitro de différentes concentrations des extraits $(50-200 \mathrm{mg} / \mathrm{ml})$ et d'un antibiotique standard (ciprofloxacine) ont été testées sur quatre bactéries entériques (S. typhi, S. flexneri, E. coli, P. vulgaris) par le test de diffusion sur gélose. Les activités antibactériennes in vivo des deux plantes ont également été testées par administration orale quotidienne de $2000 \mathrm{mg} / \mathrm{kg}$ de poids corporel (pendant 7 jours) de chaque extrait sur des souris consanguines infectées par inoculation intrapéritonéale d'une dose infectieuse de chacune des quatre bactéries entériques. Les données ont été calculées en tant que moyenne \pm erreur standard et analysées par le système d'analyse statistique (SAS) version 9.4. Les associations entre les variables ont été déterminées à l'aide d'une analyse de variance (ANOVA), avec $p<0,05$ considéré comme une valeur significative.

Résultats: L'analyse phytochimique des extraits bruts des deux plantes a révélé la présence de glycosides cardiaques, de saponines, d'alcaloïdes, de flavonoïdes et de tanins mais $V$. paradoxa contient plus de glucides et d'amidon, et moins de phlobatannins, par rapport à $E$. heterophylla. Un essai in vitro a montré une activité antibactérienne dose-dépendante des extraits au méthanol, aqueux et au chloroforme (mais pas à l'éther de pétrole) des deux racines des plantes. Les activités antibactériennes in vitro des différents extraits d'extraits de $V$. paradoxica étaient significativement plus élevées (diamètres moyens des zones d'inhibition plus élevés) que celles d'E. heterophylla $(p<0,05)$, et les extraits au méthanol ont donné les effets antibactériens les plus élevés. Cependant, l'extrait de racine d'E. heterophylla a donné une activité antibactérienne plus élevée avec le test in vivo sur des souris consanguines que $V$. paradoxa, et les extraits au méthanol des deux extraits de plantes ont donné l'activité in vivo la plus élevée, suivie par l'extrait aqueux et l'activité la plus faible a été obtenu avec l'extrait chloroformique.

Conclusion: Des extraits bruts de racines d'E. heterophylla et de $V$. paradoxa produisent une activité antibactérienne contre les bactéries pathogènes entériques à Gram négatif impliquées dans les maladies diarrhéiques. D'autres recherches devraient être dirigées vers l'isolement et la caractérisation des composés actifs dans les extraits bruts.

Mots-clés: racines; phytochimiques; in vitro; in vivo; Euphorbia heterophylla; Vitellaria paradoxa; bactéries entériques

\section{Introduction:}

Plants basically consist of $32 \%$ of the earth surface (1). There are about half a million plants now growing on earth, many of which possess therapeutic and pharmaceutical properties (2). According to an earlier survey, about $25 \%$ of modern drugs and medicinal products are derived from secondary metabolites of plant (3). Most of these plants are said to be beneficial in attaining stable health and treatment of most human diseases, and as such, are termed medicinal plants. Medicinal plants can be described as natures' pharmacy for nearly $80 \%$ of people living in Africa (4). A medicinal plant has been described as any plant in which one or more of its parts contain substances that can be used for therapeutic purpose or which acts as precursors for the synthesis of useful drugs (5). In Africa, based on cultural acceptability and fewer side effects, herbal medicine still remains the mainstay of treatment in $75-80 \%$ of the population at the primary health care (6). In Nigeria, thousands of plant species are known to have medicinal values (5) and the use of different parts of several medicinal plants to cure specific ailments has been in vogue since ancient times (7). In the present scenario of emergence of multiple drug resistance in human pathogenic microorganisms, this has necessitated a search for new antimicrobial substances from plants.

However, the ability of plants to produce many phytochemicals used to perform important biological functions is one of the many characteristics they possess, and the medicinal values of these plants lie in the phytochemicals present in the plants, which in turn produce definite physiological actions in the human body $(8,9,10)$. Phytochemicals are nonnutritive plant chemicals that have protective or disease preventive properties. It is a well- 
known fact that plants produce these chemicals to protect themselves, and recent researches have demonstrated that they can also protect humans against various diseases. These chemical substances possess varied activities such as antioxidant, hormonal, stimulatory, antimicrobial, anti-diarrhoeal, anti-histamine, anti-diabetic, anti-malarial and anti-carcinogenic effects. In most cases, due to the presence of these bioactive compounds or phytochemicals, plants may be considered as potential candidates for developing new antimicrobial drugs or alternative treatments of various ailments caused by microorganisms resistant to most commonly available synthetic drugs.

Two efficient medicinal plants that are gradually gaining grounds in the developing countries due to their medicinal benefits are Euphorbia heterophylla and Vitellaria paradoxa.

$E$. heterophylla is one of the numerous plants found in the field, which grows in disturbed localities as a weed of cultivation and waste land, in gardens, and along roadsides from sea-level up to $3000 \mathrm{~m}$ altitude (11). It belongs to the family of Euphorbiaceae, and is referred to as Mexican fire plant, milk weed and Spurge weed in English, and commonly called Nonokunchiya in Hausa, Egele in Ibo and Adimeru among the Yoruba tribes in Nigeria (12). All the parts of $E$. heterophylla contain latex (11), and the plant is widely used in traditional African medicine and elsewhere in tropical countries. Generally, this plant is regarded as a purgative, anti-asthmatic, anti-inflammatory and an abortifacient $(13,14)$, and has also been reported to be oxytocic (15). In East Africa, the roots are used in the treatment of gonorrhoea and to increase milk production in breast-feeding women (15). Vitellaria paradoxa on the other hand, is generally regarded as a deciduous and multipurpose plant, found and used in Africa. The size of the mature tree of $V$. paradoxa varies from 7 to $25 \mathrm{~m}$. This plant belongs to the family Sapotaceae and is said to produce shea butter as its main product (16). V. paradoxa was formerly called Butyrospermum parkii (which means butter seed) but could also be called Butyrospermum paradoxa. In Nigeria, it is locally known as 'emi-emi' among the Yorubas, 'ka'danya' among the Hausas and 'okwuma' among the Igbos (17). The plant is said to possess white latex. The shea tree grows naturally in the wild in the dry savannah belt of West Africa from Senegal in the west to Sudan in the east, and onto the foothills of the Ethiopian highlands. The roots are used as chewing sticks in Nigeria, which is common in savannah areas (17). Roots and root barks are ground to paste and taken orally to cure jaun- dice, stomach ache and diarrhoea or can be boiled and pound into paste to treat chronic sores $(17,18)$. These plants generally are used for the treatment of diseases caused by enteric bacteria which are known to be associated with high morbidity and mortality in humans. Enteric bacteria are usually Gram-negative bacteria which are mostly gastrointestinal flora but can cause diarrhoea or other diseases (19). They are also found in various natural habitats aside the intestinal tract. Most enteric bacteria are motile by peritrichous flagella with two major exceptions; Klebsiella and Shigella, which lack peritrichous flagella (20). Many of the enteric bacteria are facultatively anaerobic in nature, a trait that allows them to thrive in the gut environment, and most produce energy by metabolizing sugars into lactic acid. Some of the enteric bacteria live in the gut without causing diseases in individuals with good host immune system while some almost always cause enteric diseases manifesting with symptoms and signs such as vomiting, diarrhoea, and other related features (19). Based on the health-related threats pose by these enteric bacteria, individuals in the populace tend to overuse and misuse available synthetic drugs, which thereby lead to emergence of resistance in the population of these enteric bacteria. It is therefore imperative to seek other alternative sources of remedy to various enteric diseases and determine the differences between them, which forms the main objective of this study.

\section{Materials and method:}

\section{Collection and identification of plant materials} Fresh samples of the roots of both plants (Euphorbia heterophylla and Vitellaria paradoxa) were collected from Garatu, in a village called Anguwan noma, which lies on longitude $6.44^{\circ} \mathrm{N}$ and latitude $9.4^{\circ} \mathrm{E}$. The plant samples were identified and confirmed at the Department of Biological Sciences, Federal University of Technology, Minna, Nigeria.

\section{Extraction procedure}

The roots of both plants were thoroughly washed, air dried at room temperature $\left(28^{\circ} \mathrm{C}\right)$, and ground into coarse powder using a sterile mortar and pestle. The dried roots were further ground into a fine powder using an electric blender, which was done to enhance the penetration of the extracting solvent to facilitate the release of the active components (21). One hundred grammes $(100 \mathrm{~g})$ of each ground root was macerated successively for three days (with occasional shaking) using cold maceration technique. One liter $(1000 \mathrm{ml})$ each 
of distilled water, methanol, chloroform, and petroleum ether were used as the extraction solvents. The macerated samples were sieved with muslin cloth and evaporated to dryness using a steam bath. The dried extracts were weighed and stored in sterile sample bottles and kept in the refrigerator for further studies (21).

Extracts were reconstituted by dissolving different weights of each dried extract $(0.05 \mathrm{~g}, 0.1 \mathrm{~g}, 0.15 \mathrm{~g}$ and $0.2 \mathrm{~g})$ in $1 \mathrm{ml}$ of either distilled water or dimethyltetrasulphuric acid $\left(\mathrm{DMSO}_{4}\right)$, to give concentrations of $50 \mathrm{mg} / \mathrm{ml}$, $100 \mathrm{mg} / \mathrm{ml}, 150 \mathrm{mg} / \mathrm{ml}$ and $200 \mathrm{mg} / \mathrm{ml} \mathrm{respec}-$ tively. Similarly, the standard antibiotic (ciprofloxacin) was reconstituted by dissolving different weights of the dry antibiotic powder $(0.05$ $\mathrm{g}, 0.1 \mathrm{~g}, 0.15 \mathrm{~g}$ and $0.2 \mathrm{~g}$ ) in $1 \mathrm{ml}$ of distilled water to produce equivalent concentrations as the extracts.

\section{Phytochemical screening}

The phytochemical screenings of the crude extracts of both roots were carried out to detect the presence or absence of some secondary metabolites according to previously described methods $(22,23)$.

\section{Test bacteria and culture media}

The test organisms (Salmonella typhi, Shigella flexneri, Escherichia coli and Proteus vulgaris) were obtained from the stock cultures of the Microbiology Laboratory, General Hospital, Minna, Niger State, Nigeria. MacConkey, Salmonella-Shigella (SS) and Nutrient agar plates were used as differential, selective and for susceptibility testing media of the test bacteria as previously described (24).

\section{In vitro antibacterial assay of crude extracts}

A 24-hour well-grown activated cultures of each test bacterium were serially diluted in test tubes with normal saline and standardized with MacFarland turbidity standards to obtain inoculum equivalent to $1.0 \times 10^{5} \mathrm{CFU} / \mathrm{ml}$. The antibacterial assay of the crude extracts of the roots of both plants was done using the agar (punch hole) diffusion method as described by Idu and Igekele (24). The Nutrient agar plates were prepared by dispensing $20 \mathrm{ml}$ of sterile molten nutrient agar into sterile Petri plates and allowed to set, and then inoculated with the standardized inoculum of each test bacterium using sterile cotton swab. A $4 \mathrm{~mm}$ sterile cork-borer was used to punch five (5) adequately spaced holes in each inoculated agar plates to create wells. Approximately 0.2 $\mathrm{ml}$ of the different concentrations $(50 \mathrm{mg} / \mathrm{ml}$, $100 \mathrm{mg} / \mathrm{ml}, 150 \mathrm{mg} / \mathrm{ml}$ and $200 \mathrm{mg} / \mathrm{ml}$ ) of the extracts and the standard antibiotic, was introduced into each well. The Petri plates were incubated at a temperature of $37^{\circ} \mathrm{C}$ for 24 hours, after which diameter of inhibition zones around each well was measured with a calibrated ruler. The diameters of inhibition zones produced by the extracts were compared with that produced by the standard antibiotic (ciprofloxacin) used as control (24). Extracts of each plant that showed little or no antibacterial activity were excluded for the in vivo assay.

\section{In vivo antibacterial activity of crude extracts}

\section{Experimental animals}

Inbred mice within the age of 8-12 weeks with body weight from 18-22 g were acquired from Ibrahim Badamosi Babangida University Lapai, Nigeria. The mice were kept in standard cages with adequate food, water and under hygienic conditions for 2 weeks before inoculation (25).

Preparation of inoculum of test bacteria A loopful of the test bacteria was inoculated on Salmonella-Shigella agar which was incubated aerobically at $37^{\circ} \mathrm{C}$ to activate the them. Colonies of the test bacteria were then transferred into test tubes containing 10 $\mathrm{ml}$ of sterile nutrient broth and incubated at $37^{\circ} \mathrm{C}$ for $18-24$ hours. The culture was serially diluted in test tubes with normal saline and standardized with McFarland turbidity standards to obtain inoculum equivalent to $1.0 \times$ $10^{5} \mathrm{CFU} / \mathrm{ml}$ (26).

Inoculation of mice with test organisms and administration of plant extracts and standard antibiotic

The mice were divided into 28 groups, with each group containing 5 mice $(n=5)$. In each group, $1 \mathrm{ml}$ of the standardized inoculum (containing $1.0 \times 10^{5} \mathrm{CFU}$ as infective dose) of each of the test bacterium (E. coli, S. typhi, $S$. flexneri, and $P$. vulgaris) was introduced into each mouse intraperitoneally (26). After 72 hours, inoculated mice in each group were administered daily with $2,000 \mathrm{mg} / \mathrm{kg} / \mathrm{body}$ weight of chloroform, methanolic and aqueous root extracts of $E$. heterophylla and $V$. paradoxa, and the control (ciprofloxacin) antibiotic, orally for 7 days (27). The mice were closely observed daily after inoculation and the mortality rate and other physical manifestations were recorded.

\section{Observation of physical manifestations, survival and mortality}

The mortality and survival rates of the mice in the groups were calculated as numbers 
of mice that died and survived during the course of the experiment in relation to all the mice that were used (26). The animals were observed for frequency, consistency, and the colour of their faecal wastes, and for abnormallities and physical manifestations such as loss of appetite, weight loss and body weakness, during the period of the experiment (27). At the end of the study, infected mice were sacrificed using chloroform and buried, to prevent the spread of the infection associated with enteric pathogens in the environment (27)

\section{Statistical analysis}

Data were presented as mean \pm standard error of mean, and analyzed using the Statistical Analysis System (SAS) version 9.4. Associations between variables were determined using analysis of variance (ANOVA), with $p<0.05$ considered as significant value.

\section{Results:}

Phytochemical constituents of root extracts of the plants

The phytochemical components of $E$. heterophylla roots were alkaloids, flavonoids, saponins, tannins and cardiac glycosides with all the crude extract solvents while compounds such as carbohydrates and starch were mostly found in $V$. paradoxa (Table 1 ).

\section{In vitro antibacterial activity of extracts and control antibiotic}

Tables 2.1 to 5.2 represent the mean diameters of the inhibition zones of chloroform, methanol, petroleum ether and aqueous extracts of $V$. paradoxa and $E$. heterophylla, and the control (ciprofloxacin) antibiotic, on all the bacterial strains (S. typhi, S. flexneri, E. coli and $P$. vulgaris) tested in this study

Table 1: Phytochemical constituents of root extracts of Euphorbia heterophylla and Vitellaria paradoxa

\begin{tabular}{|c|c|c|c|c|c|c|c|c|}
\hline \multirow[t]{2}{*}{ Phytochemical compound } & \multicolumn{4}{|c|}{ Euphorbia heterophylla } & \multicolumn{4}{|c|}{ Vitellaria paradoxa } \\
\hline & Chloroform & Methanol & Aqueous & $\begin{array}{l}\text { Petroleum } \\
\text { Ether }\end{array}$ & Chloroform & Methanol & Aqueous & $\begin{array}{l}\text { Petroleum } \\
\text { Ether }\end{array}$ \\
\hline Carbohydrates & - & + & + & - & + & + & + & + \\
\hline Starch & - & + & + & - & + & + & + & + \\
\hline Saponins & + & + & + & + & + & + & + & + \\
\hline Steroids & - & + & + & - & - & + & + & - \\
\hline Alkaloids & + & + & + & + & + & + & + & - \\
\hline Flavonoids & + & + & + & + & - & + & + & + \\
\hline Tannins & + & + & + & + & + & + & + & + \\
\hline Phlobatannins & - & + & _ & + & _- & - & - & _- \\
\hline
\end{tabular}


The tables show dose-dependent antibacterial activity of the root extracts of both $\mathrm{V}$. paradoxa and $E$. heterophylla on all the bacterial strains and for all the extracting solvents (except petroleum ether) as shown by the progressive increase in mean diameters of inhibition zones, with increasing doses from 50 $\mathrm{mg} / \mathrm{ml}$ to $200 \mathrm{mg} / \mathrm{ml}$ of the extracts. However, methanol, aqueous and chloroform root extracts of $V$. paradoxa (VPMR, VPAR and VPCR) had significantly higher antibacterial activity ( $p$ $<0.05$ ) on all the test bacteria as shown by significantly wider mean diameters of inhibition zones from $50 \mathrm{mg} / \mathrm{ml}$ to $200 \mathrm{mg} / \mathrm{ml}$ extract concentrations, compared to methanol, aqueous and chloroform root extracts of $E$. heterophylla (EHMR, EHAR and EHCR).

The antibacterial activity was highest

Table 2.1: Zones of inhibition of extract of V. paradoxa at $50 \mathrm{mg} / \mathrm{ml}$

\begin{tabular}{|c|c|c|c|c|}
\hline Extracts & $\begin{array}{l}\vdots \\
\vdots \\
\text { v }\end{array}$ & 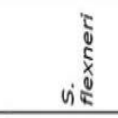 & $\begin{array}{r}\text { o } \\
\text { uj }\end{array}$ & 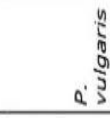 \\
\hline VPCR & $2.67 \pm 0.33^{d}$ & $2.33 \pm 0.33^{c}$ & $2.00 \pm 0.60^{c}$ & $2.00 \pm 0.00^{b}$ \\
\hline VPMR & $9.33 \pm 0.33^{c}$ & $7.00 \pm 0.58^{\circ}$ & $9.33 \pm 0.33^{c}$ & $8.67 \pm 0.33^{\circ}$ \\
\hline VPAR & $9.00 \pm 0.58^{c}$ & 5. $33 \pm 0.58^{b}$ & $8.33 \pm 0.67^{c}$ & $7.67 \pm 0.68^{\circ}$ \\
\hline VPPR & $2.33 \pm 0.31^{\mathrm{ed}}$ & $1.67 \pm 0.34^{b c}$ & $2.00 \pm 0.00^{c}$ & $1.67 \pm 0.70^{b}$ \\
\hline CONTROL & $18.00 \pm 0.58^{d}$ & $17.33 \pm 0.67^{c}$ & $17.00 \pm 0.58^{d}$ & $14.33 \pm 0.67^{d}$ \\
\hline
\end{tabular}

Table 3.1: Zones of Inhibition of the root of $V$. paradoxa at $100 \mathrm{mg} / \mathrm{ml}$

\begin{tabular}{|c|c|c|c|c|}
\hline Extracts & $\operatorname{cis}$ & 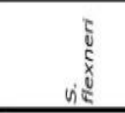 & $\begin{array}{c}\overline{8} \\
0 \\
\text { แ் }\end{array}$ & $\begin{array}{r}5 \\
0 \\
03 \\
03 \\
0.30\end{array}$ \\
\hline VPCR & $8.33 \pm 0.33^{\mathrm{de}}$ & $6.67 \pm 0.90^{5}$ & $8.00 \pm 0.00^{d}$ & $6.00 \pm 1.00^{b}$ \\
\hline VPMR & $12.67 \pm 0.33^{c}$ & $11.33 \pm 0.33^{6}$ & $11.33 \pm 0.67^{\circ}$ & $11.00 \pm 0.50^{c}$ \\
\hline VPAR & $11.00 \pm 0.58$ & $10.00 \pm 0.58^{b}$ & $10.33 \pm 0.31^{\text {cd }}$ & $9.67 \pm 0.30^{b}$ \\
\hline VPPR & $7.00 \pm 1.00$ dd & $6.00 \pm 0.57^{\circ c}$ & $6.33 \pm 0.33^{\mathrm{cd}}$ & $5.67 \pm 0.70^{b}$ \\
\hline CONTROL & $24.67 \pm 0.33^{d}$ & $23.00 \pm 0.00^{c}$ & $24.00 \pm 0.58^{d}$ & $20.00 \pm 0.58 \mathrm{c}$ \\
\hline
\end{tabular}

for methanol root extract of both $E$. heterophylla and $V$. paradoxa followed by aqueous and chloroform root extract, while petroleum ether root extracts of both $V$. paradoxa (VPPR) and $E$. heterophylla (EHPR) showed the least antibacterial activity from $50 \mathrm{mg}$ to $200 \mathrm{mg} / \mathrm{ml}$ extract concentrations as shown by the narrowwest diameters of inhibition zones compared to the root extracts of the three other solvents. Hence, petroleum ether root extract was excluded from the in vivo experiment. The antibacterial activity of the control antibiotic (ciprofloxacin) was however significantly higher (wider diameters of inhibition zones) than the different solvent root extracts of the two plants at all the concentrations tested, although this was not in a dose-dependent manner.
Table 2.2: Zones of inhibition of extract of $E$. heterophylla at $50 \mathrm{mg} / \mathrm{ml}$

\begin{tabular}{|c|c|c|c|c|}
\hline Extracts & vis & 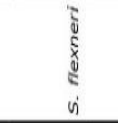 & $\begin{array}{l}\overline{8} \\
\text { uे }\end{array}$ & $\begin{array}{r}n \\
5 \\
0 \\
0 \\
0\end{array}$ \\
\hline EHCR & $2.00 \pm 0.58^{b}$ & $1.67 \pm 0.33^{\circ}$ & $1.67 \pm 0.33^{a b}$ & $2.00 \pm 0.58^{b}$ \\
\hline EHMR & $4.33 \pm 0.33^{\mathrm{cdef}}$ & $4.00 \pm 0.58$ cde & $4.67 \pm 0.33^{\mathrm{de}}$ & $3.67 \pm 0.33^{c}$ \\
\hline EHAR & $3.67 \pm 0.33^{\mathrm{bcd}}$ & $3.67 \pm 0.67^{c d}$ & $5.00 \pm 0.58^{d e}$ & $3.67 \pm 0.66^{c}$ \\
\hline EHPR & $0.00 \pm 0.00^{a}$ & $0.00 \pm 0.00^{\circ}$ & $0.00 \pm 0.00^{\mathrm{a}}$ & $0.00 \pm 0.00^{\circ}$ \\
\hline CONTROL & $9.00 \pm 0.58$ & $8.00 \pm 0.578$ & $8.67 \pm 0.68$ & $8.67 \pm 0.33^{\circ}$ \\
\hline
\end{tabular}

Table 3.2: Zones of Inhibition of the root of E. heterophylla at $100 \mathrm{mg} / \mathrm{ml}$

\begin{tabular}{|c|c|c|c|c|}
\hline Extracts & $v \frac{1}{d}$ & 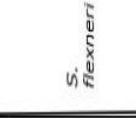 & 4) & 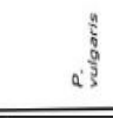 \\
\hline EHCR & $4.00 \pm 0.60^{b}$ & $4.33 \pm 0.33^{b}$ & $5.00 \pm 0.00^{\text {bed }}$ & $3.67 \pm 0.33^{\circ}$ \\
\hline EHMR & $7.67 \pm 0.30^{\text {cde }}$ & $7.33 \pm 0.33^{\text {defg }}$ & $6.33 \pm 1.76^{\text {cde }}$ & $6.67 \pm 1.20$ cd \\
\hline EHAR & $6.67 \pm 0.70^{\text {cd }}$ & $6.67 \pm 0.30^{\text {cotef }}$ & $7.00 \pm 00^{\text {cce }}$ & $6.33 \pm 0.90^{\circ} \mathrm{c}$ \\
\hline EHPR & $0.00 \pm 0.00^{\mathrm{a}}$ & $0.00 \pm 0.00^{\mathrm{a}}$ & $2.00 \pm 0.00^{0 \mathrm{ab}}$ & $0.00 \pm 0.00^{3}$ \\
\hline CONTROL & $15.00 \pm 0.60^{n}$ & $13.33 \pm 0.90$ & $13.33 \pm 1.45^{f}$ & $12.33 \pm 1.459$ \\
\hline
\end{tabular}

Values are represented as Mean \pm Standard Error of Mean of triplicate determinations. Values along the column with different alphabet is significantly $(p<0.05)$

VPCR $=$ Chloroform root extract of Vitellaria paradoxa; VPMR $=$ Methanolic root extract of Vitellaria paradoxa; VPAR $=$ Aqueous root extract of Vitellaria paradoxa; VPPR $=$ Petroleum ether root extract of Vitellaria paradoxa.; EHCR = Chloroform root extract of Euphorbia heterophylla; EHMR = Methanolic root extract of Euphorbia heterophylla; EHAR = Aqueous root extract of Euphorbia heterophylla; EHPR = Petroleum ether root extract of Euphorbia heterophylla 


\begin{tabular}{|c|c|c|c|c|}
\hline Extracts & $\operatorname{cic}$ & ve & $\begin{array}{r}\text { 8े } \\
4 \\
4\end{array}$ & $\begin{array}{r}\frac{n}{5} \\
0.5 \\
25 \\
\end{array}$ \\
\hline VPCR & $11.00 \pm 0.60^{\circ}$ & $9.67 \pm 0.90^{c d}$ & $10.00 \pm 0.58^{d}$ & $9.00 \pm 0.00^{\circ}$ \\
\hline VPMR & $14.67 \pm 0.33^{b}$ & $14.33 \pm 0.33^{c}$ & $13.00 \pm 0.56^{c}$ & $12.00 \pm 0.60^{c}$ \\
\hline VPAR & $13.33 \pm 0.58^{\mathrm{ab}}$ & $12.00 \pm 0.58^{\mathrm{ab}}$ & $11.67 \pm 0.90^{\mathrm{abc}}$ & $10.67 \pm 0.86^{\mathrm{bc}}$ \\
\hline VPPR & $8.67 \pm 0.67^{\mathrm{a}}$ & $7.67 \pm 0.70^{b c}$ & $7.67 \pm 0.33^{c}$ & $7.33 \pm 0.68^{b}$ \\
\hline CONTROL & $27.00 \pm 0.58^{c}$ & $26.00 \pm 0.58^{d}$ & $26.33 \pm 0.33^{d}$ & $25.67 \pm 0.33^{d}$ \\
\hline
\end{tabular}

Table 5.2: Zones of Inhibition of the root of $V$. paradoxa at $200 \mathrm{mg} / \mathrm{ml}$

\begin{tabular}{|c|c|c|c|c|}
\hline Extracts & vid & 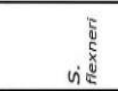 & $\begin{array}{l}\overline{0} \\
\text { 4i }\end{array}$ & $\begin{array}{r}\frac{n}{5} \\
0.5 \\
0.5 \\
5\end{array}$ \\
\hline VPCR & $12.67 \pm 0.33^{d}$ & $11.33 \pm 0.88^{6}$ & $12.00 \pm 0.60^{e}$ & $11.33 \pm 0.70^{\circ}$ \\
\hline VPMR & $17.00 \pm 0.58^{b}$ & $15.00 \pm 0.58^{b}$ & $14.68 \pm 0.33^{b}$ & $14.68 \pm 0.90^{\circ}$ \\
\hline VPAR & $15.68 \pm 0.88^{b}$ & $14.67 \pm 0.67^{\circ}$ & $13.67 \pm 0.70^{b}$ & $11.33 \pm 0.30^{\mathrm{a}}$ \\
\hline VPPR & $9.67 \pm 0.33^{c}$ & $8.33 \pm 1.20^{\mathrm{bc}}$ & $9.00 \pm 0.00^{\mathrm{bc}}$ & $7.33 \pm 1.20^{\circ \mathrm{c}}$ \\
\hline CONTROL & $30.00 \pm 0.58^{c}$ & $29.67 \pm 0.33^{c}$ & $29.33 \pm 0.67 c$ & $28.00 \pm 0.58^{c}$ \\
\hline
\end{tabular}

Table 4.2: Zones of Inhibition of the root of $E$. heterophylla at $150 \mathrm{mg} / \mathrm{ml}$

\begin{tabular}{|c|c|c|c|c|}
\hline Extracts & $\begin{array}{l}\frac{1}{2} \\
2 \\
\text { vi }\end{array}$ & 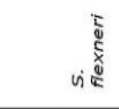 & $\begin{array}{l}\overline{8} \\
\text { uे }\end{array}$ & $0 . \frac{n}{5}$ \\
\hline EHCR & $5.33 \pm 0.70^{b}$ & $4.67 \pm 0.28^{b}$ & $5.00 \pm 0.60^{b}$ & $4.33 \pm 0.90^{b}$ \\
\hline EHMR & $8.33 \pm 0.90^{c}$ & $8.00 \pm 0.60^{c}$ & $8.33 \pm 0.88^{c}$ & $7.67 \pm 0.90^{\circ}$ \\
\hline EHAR & $8.67 \pm 0.30^{c}$ & $7.67 \pm 0.90^{c}$ & $8.33 \pm 0.33^{c}$ & $8.33 \pm 0.30^{c}$ \\
\hline EHPR & $2.67 \pm 0.30^{\mathrm{a}}$ & $1.67 \pm 0.90^{a}$ & $2.00 \pm 0.30^{\mathrm{a}}$ & $1.33 \pm 0.33^{\mathrm{a}}$ \\
\hline CONTROL & $20.00 \pm 0.60^{t}$ & $18.67 \pm 0.70^{9}$ & $19.33 \pm 0.339$ & $19.00 \pm 0.58^{\prime}$ \\
\hline
\end{tabular}

Table 5.2: Zones of Inhibition of the root of $E$. heterophylla at $200 \mathrm{mg} / \mathrm{ml}$

\begin{tabular}{|c|c|c|c|c|}
\hline Extracts & $\begin{array}{l}\frac{\pi}{d} \\
\text { i } \\
\text { vi }\end{array}$ & $\begin{array}{r}5 \\
\text { vis } \\
\text { vi }\end{array}$ & $\begin{array}{l}\text { ठิ } \\
\text { யं }\end{array}$ & $\begin{array}{r}\frac{n}{5} \\
0 \\
0 \\
0 \\
0 \\
3\end{array}$ \\
\hline EHCR & $8.33 \pm 0.33^{b}$ & $7.00 \pm 0.60^{\circ}$ & $8.33 \pm 0.33^{b}$ & $7.33 \pm 0.67^{b c}$ \\
\hline EHMR & $11.00 \pm 00^{\text {de }}$ & $10.33 \pm 0.33^{\mathrm{de}}$ & $10.67 \pm 0.70^{c d}$ & $9.67 \pm 0.30^{\mathrm{de}}$ \\
\hline EHAR & $11.00 \pm 0.00^{\text {de }}$ & $10.33 \pm 0.33^{\mathrm{de}}$ & $10.67 \pm 0.30^{\text {cd }}$ & $10.00 \pm 0.60^{d e}$ \\
\hline EHPR & $3.67 \pm 0.30^{\mathrm{s}}$ & $2.67 \pm 0.70^{a}$ & $3.33 \pm 0.67^{\mathrm{a}}$ & $3.00 \pm 0.60^{\mathrm{a}}$ \\
\hline CONTROL & $26.00 \pm 0.60^{h}$ & $25,00 \pm 0.70^{9}$ & $25.33 \pm 0.33^{f}$ & $24.33 \pm 0.33^{9}$ \\
\hline
\end{tabular}

Values are represented as Mean \pm Standard Error of Mean of triplicate determinations. Values along the column with different alphabet is significantly $(p<0.05)$

VPCR $=$ Chloroform root extract of Vitellaria paradoxa; VPMR = Methanolic root extract of Vitellaria paradoxa; VPAR = Aqueous root extract of Vitellaria paradoxa; VPPR = Petroleum ether root extract of Vitellaria paradoxa.; EHCR = Chloroform root extract of Euphorbia heterophylla; EHMR = Methanolic root extract of Euphorbia heterophylla; EHAR = Aqueous root extract of Euphorbia heterophylla; EHPR = Petroleum paradoxa.; EHCR = Chloroform root extract
ether root extract of Euphorbia heterophylla

\section{In vivo antibacterial activity of the extracts}

Fig 1 represents the in vivo effects of chloroform, methanol and aqueous extracts of $V$. paradoxa and $E$. heterophylla on mice infected with $S$. typhi showing antibacterial activity of the extracts in the order E.h/M $>V . p / M>$ E.h/A $>$ V.p/C>V.p/A $>$ E.h/C. This indicates that methanol extracts of $E$. heterophylla demonstrated the greatest in vivo antibacterial activity resulting in only $20 \%$ of the infected mice having diarrhoea between 1-3 days, and none $(0 \%)$ manifesting pathological symptoms of diarrhoea, weight loss, loss of appetite and body weakness after 4 days of extract administration. Comparatively, chloroform extract of $E$. heterophylla demonstrated the least in vivo activity as shown by high percentage (40-60\%) of infected mice showing pathological symptoms of diarrhoea, weight loss, loss of appetite and body weakness after 4 days, and up till the $7^{\text {th }}$ day of extract administration.

Fig 2 presents the in vivo effects of the extracts of $V$. paradoxa and $E$. heterophylla on mice infected with $S$. flexneri showing antibacterial activity of the extracts in the order E.h/M >V.p/M >V.p/A>E.h/C >E.h/A>V.p/C. The methanol extracts of $E$. heterophylla demonstrated the highest in vivo antibacterial activity with only $40 \%$ and $20 \%$ of the infected mice manifesting diarrhoea symptoms between 1-3 days and 4-6 days respectively, and none (0\%) showing symptoms of weight loss, loss of appetite and body weakness after 5 days of extract administration. Conversely, chloroform extracts of $V$. paradoxa demonstrated the lowest in vivo activity as shown by the high percentage ( 80 $\%$ ) of infected mice showing symptoms of diarrhoea in 1-3 days and 4-6 days, and 40\% showing symptoms of weight loss, loss of appetite and body weakness after 5 days and up till the $7^{\text {th }}$ day of extract administration.

Fig 3 represent the in vivo effects of the extracts of $V$. paradoxa and $E$. heterophylla on mice infected with $E$. coli showing antibacterial activity of the extracts in the order E.h/M >V.p/M >E.h/A >V.p/A >V.p/C>E.h/C. The methanol extracts of $E$. heterophylla demonstrated the highest in vivo activity with only $60 \%$ and $20 \%$ of infected mice showing pathological symptoms of diarrhoea in 1-3 days and 4-6 days respectively, while none ( $0 \%)$ showed symptoms of diarrhoea, weight loss, loss of appetite and body weakness after 5 days of extract administration. However, chloroform extracts of $E$. heterophylla demonstrated the lowest in vivo activity as shown by the high percentage of infected mice (100\%) manifesting diarrhoea symptoms in 1-3 days, and $40 \%$ with diarrhoea, weight loss, loss of appe- 
tite and body weakness after 4 days and up till the $7^{\text {th }}$ day of extract administration.

Fig 4 represent the in vivo effects of the extracts of $V$. paradoxa and $E$. heterophylla on mice infected with $P$. vulgaris showing antibacterial activity of the extracts in the order E.h/M $>$ V.p/M $>$ E.h/A >V.p/A >V.p/C >E.h/C. The methanol extracts of $E$. heterophylla demonstrated the highest in vivo activity with only $60 \%$ and $20 \%$ of infected mice showing pathological symptoms of diarrhoea in 1-3 days and
4-6 days respectively, and none (0\%) showed symptoms of diarrhoea, weight loss, loss of appetite and body weakness after 5 days of extract administration. However, chloroform extract of $E$. heterophylla demonstrated the lowest in vivo activity as shown by the high percentage of infected mice with diarrhoea (60\%) having diarrhoea in $1-3$ days and $40 \%$ with diarrhoea, weight loss, loss of appetite and body weakness after 4 days and up till the $7^{\text {th }}$ day of extract administration.

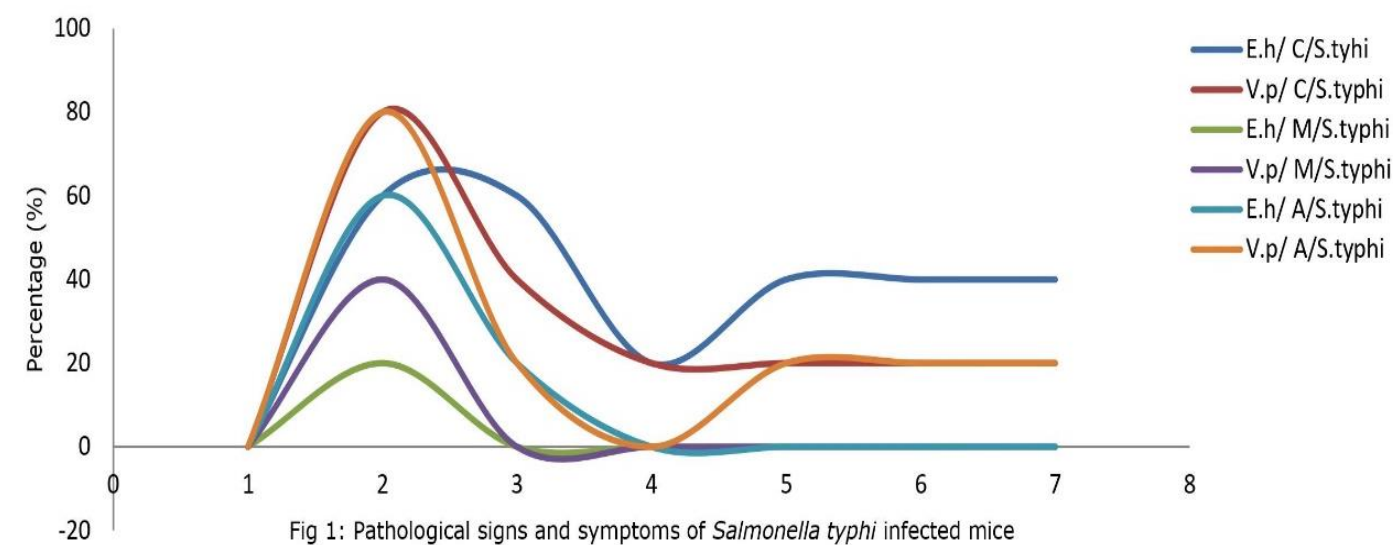

$1=$ Mortality; $2=$ Watery diarrhoea $(1-3$ days); $3=$ Watery diarrhoea $(4-6$ days $) ; 4=$ Watery diarrhoea $(>7$ days); $5=$ Weight loss; $6=$ Loss of appetite; $7=$ Body weakness; E.h $/ \mathrm{C}=$ Chloroform root extract of Euphorbia heterophylla; V.p/C = Chloroform root extract of Vitellaria paradoxa; E.h/M = Methanolic root extract of Euphorbia heterophylla; V.p/M = Methanolic root extract of Vitellaria paradoxa; E.h/A = Aqueous root extract of Euphorbia heterophylla; V.p/A = Aqueous root extract of Vitellaria paradoxa

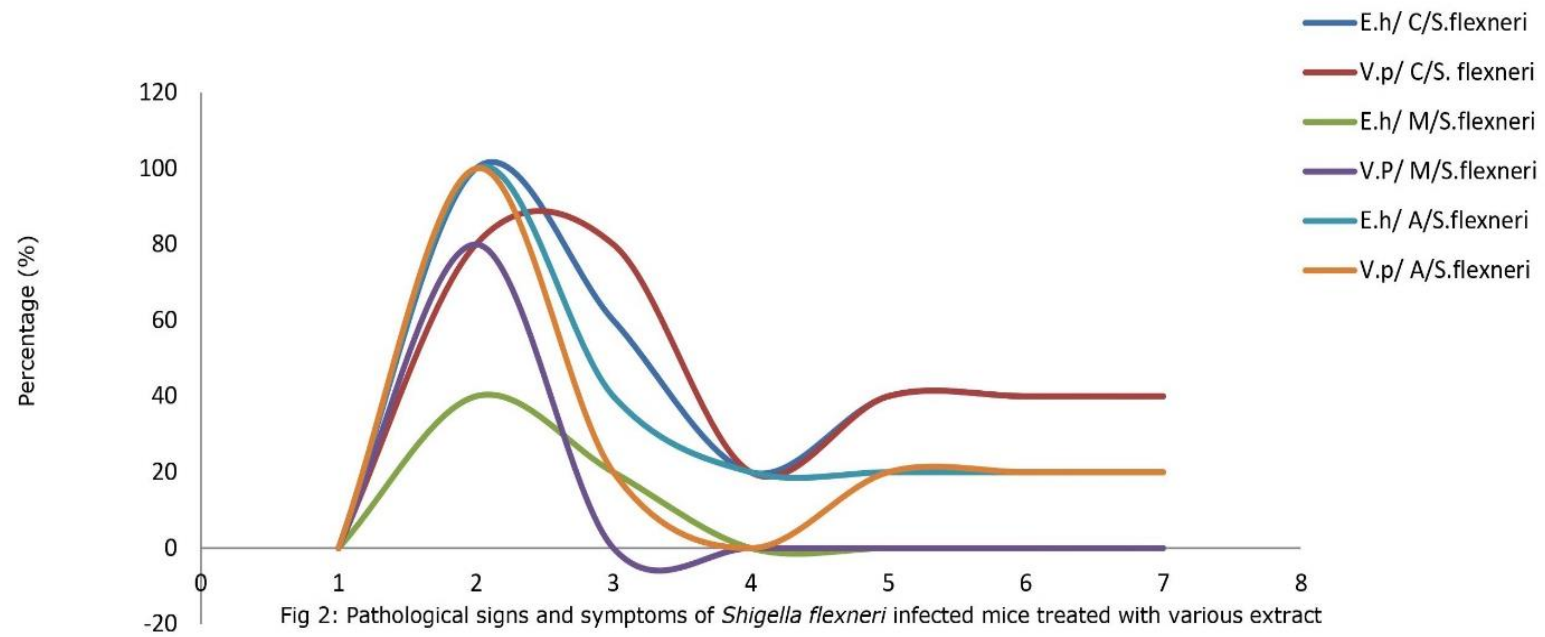

$1=$ Mortality; $2=$ Watery diarrhoea $(1-3$ days); $3=$ Watery diarrhoea $(4-6$ days); $4=$ Watery diarrhoea $(>7$ days); $5=$ Weight loss; $6=$ Loss of appetite; $7=$ Body weakness; E.h $/ \mathrm{C}=$ Chloroform root extract of Euphorbia heterophylla; $\mathrm{V} . \mathrm{p} / \mathrm{C}=$ Chloroform root extract of Vitellaria paradoxa; E.h/M $=$ Methanolic root extract of Euphorbia heterophylla; $\mathrm{V} . \mathrm{p} / \mathrm{M}=\mathrm{M}$ Methanolic root extract of Vitellaria paradoxa; E.h/A $=$ 


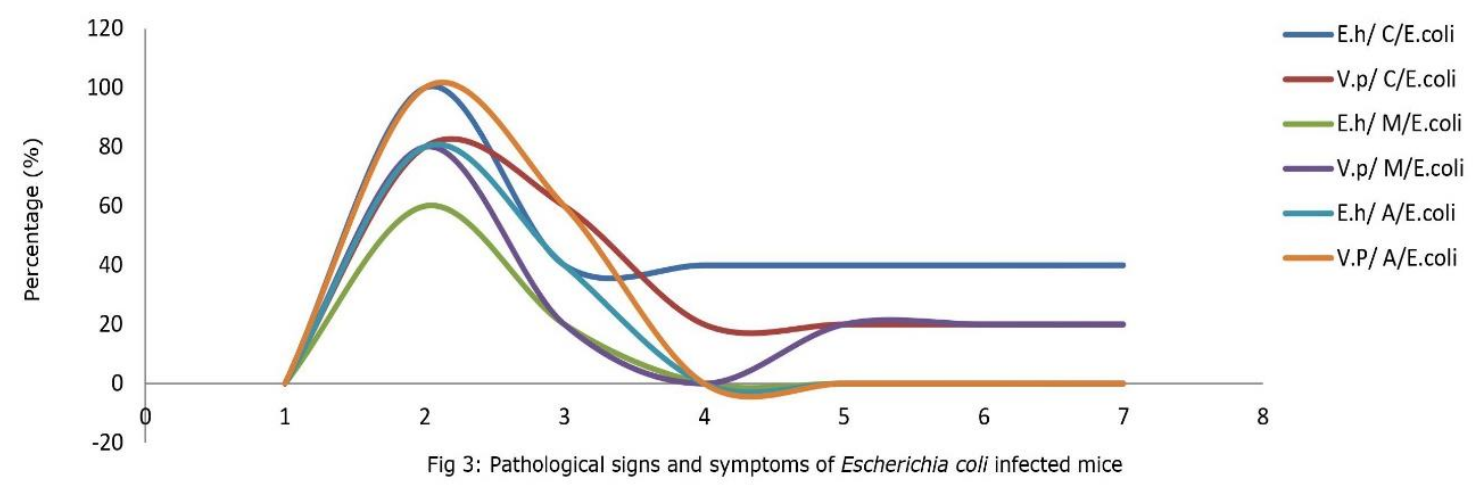

$1=$ Mortality; $2=$ Watery diarrhoea $(1-3$ days $) ; 3=$ Watery diarrhoea $(4-6$ days $) ; 4=$ Watery diarrhoea $(>7$ days); $5=$ Weight loss; $6=$ Loss of appetite; $7=$ Body weakness; E.h $/ \mathrm{C}=$ Chloroform root extract of Euphorbia heterophylla; V.p/C = Chloroform root extract of Vitellaria paradoxa; E.h/M = Methanolic root extract of Euphorbia heterophylla; V.p/M = Methanolic root extract of Vitellaria paradoxa; E.h/A = Aqueous root extract of Euphorbia heterophylla; V.p/A = Aqueous root extract of Vitellaria paradoxa

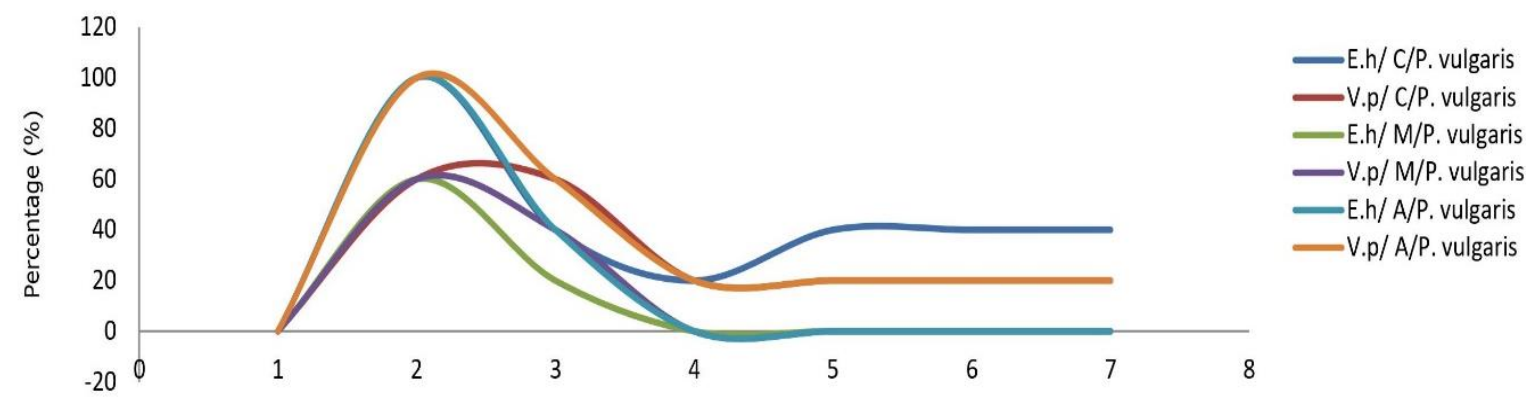

Fig 4: Pathological signs and symptoms of Proteus vulgaris infected mice

$1=$ Mortality; $2=$ Watery diarrhoea $(1-3$ days); $3=$ Watery diarrhoea $(4-6$ days); $4=$ Watery diarrhoea $(>7$ days); $5=$ Weight loss; $6=$ Loss of appetite; $7=$ Body weakness; E.h/C $=$ Chloroform root extract of Euphorbia heterophylla; $\mathrm{V} . \mathrm{p} / \mathrm{C}=$ Chloroform root extract of Vitellaria paradoxa; $\mathrm{E} . \mathrm{h} / \mathrm{M}=$ Methanolic root extract of Euphorbia heterophylla; $\mathrm{V} . \mathrm{p} / \mathrm{M}=$ Methanolic root extract of Vitellaria paradoxa; E.h/A = Aqueous root extract of Euphorbia heterophylla: $\vee p / A=$ Aqueous root extract of Vitellaria paradoxa

\section{Discussion:}

The basis of the therapeutic activities of plants lies on the phytochemical components contained in them (28), which implies that variations observed among the phytochemicals of the different plants will result in differences in their antibacterial activities. Thus, in this study, different phytochemicals were extracted in varying proportions by the solvents from the roots of the plants. Crude extracts of the roots of both $E$. heterophylla and $V$. paradoxa by the different solvents (chloroform, methanol, petroleum and water) contain cardiac glycosides, saponins, alkaloids, flavonoids, and tannins but $V$. paradoxa contain more carbohydrates and starch, and less of phlobatannins, compared to $E$. heterophylla. This is similar to the findings of Onwuliri (29), who observed the presence of phytochemicals such as phlobatannins, alkaloids, saponins, phenolics, tannins, and cardiac glycosides in tropical plants growing in Nigeria, some of which have been shown to exhibit varying biological activities, and medicinal properties (30). Mensah et al., (31) reported the importance of alkaloids, saponins and tannins in production of antibiotics used in treating common pathogenic microorganisms, which have also been known to produce definite physiological actions in the human body (32). The presence of cardiac glycosides indicates that they may act as good sedatives and antispasmodics (33). Schneider and Wolfhing (34) reported the therapeutic effects of some phytochemical constituents such as tannins and cardiac glycoside against cardiovascular diseases and digestive problems. Therefore, the presence of some of these phytochemicals in different proportions in the roots of the two plants in this study may be responsible for the observed in vitro and in vivo antibacterial activities.

In this study, there was a great disparity in the results obtained from the anti- 
bacterial activities of the root extracts of both $E$. heterophylla and $V$. paradoxa in the in vitro and in vivo assays, and with regards to the different solvents used for extraction. The in vitro study showed that root extract of $V$. paradoxa had higher antibacterial activity than $E$. heterophylla for all the extracting solvents and on all the test bacteria, while the in vivo study showed that the root extract of $E$. heterophylla had higher antibacterial activity against infected mice than $V$. paradoxa, especially with methanol as solvent. The reason for this disparaging observation is not apparent because both plants had comparatively similar contents of phytochemicals except that $V$. paradoxa had more carbohydrates and starch, and less phlobatannins, which cannot explain the difference in the conflicting antibacterial activity. However, the study by Calixto (35) reported that differences in antibacterial activity of plants could be due to differences in geographical location, season of plant, age of the plant, and method of extraction, all of which can affect the yield and the active constituents of medicinal plants. Similarly, differences observed in the antibacterial activities of both root extracts could be attributed to the penetrating effects of the different solvents. Nevertheless, methanol appeared the best of all the four extracting solvents in this study for both plant extracts, and although the antibacterial activities of the methanol root extracts of both plants were lower compared to the standard antibiotic (ciprofloxacin), the finding in our study is significant if one considers that only crude extraction was done while the probable active antibacterial components of the plants were not characterized or purified.

We noted that $40 \%$ of mice infected with S. typhi, E. coli and P. vulgaris treated with chloroform root extract of $E$. heterophylla, and $40 \%$ of mice infected with $S$. flexneri treated with root extract of $V$. paradoxa showed pathological symptoms of watery diarrhoea, weight loss, loss of appetite and body weakness after 4 days, and up till the $7^{\text {th }}$ day of extract administration, as compared to the groups of infected mice treated with methanol and aqueous extracts. The presence of diarrhoea (caused by the inoculated bacteria) in the infected mice after 4 days implies that chloroform extract produced poorer yield of the antibacterial components required for in vivo efficacy of the two plants, compared to the methanol and aqueous extracts. Aside this, the presence of weight loss, loss of appetite and body weakness, which though may be consequences of diarrhoea in the infected mice, could also be attributed to the physiological adaptation of the mice to chloroform, which can lead to low appetite and lower caloric intake by the animals. This condition has been previously reported by Rhiouani et al., (36). Furthermore, chloroform and some other extraction solvents can trigger abnormal behavioral changes in test animals, as reported by Pillai et al., (37), who observed reversible treatment-related behavioral signs such as apathy and reduced locomotor behavior in mice during toxicity test with methanolic leaf extract of Plectranthus amboinicus.

\section{Conclusion:}

Crude extracts of E. heterophylla and $V$. paradoxa produce in vitro antibacterial activity against the enteric Gram-negative bacteria pathogens involved in diarrhoea illnesses, in a dose-dependent manner. Methanol extract produced the best in vitro and in vivo antibacterial activities for both plants, while chloroform extracts produced the least antibacterial effects, and may also have been responsible for the physiological adaptations in the mice resulting in body weakness, loss of appetite and weight loss. Further researches should be directed towards isolation and characterization of the active compounds in the crude extracts

\section{References:}

1. Ghose, T. Earth get greener as globe gets hotter live science. 2016; Retrieved on August 10,2017. http://www.livescience.com/54579-earth-isgreening-as-globe-warms.htm

2. Muller, L. P. Importance of secondary metabolites constituents as drugs. Phytother. 1973; 3: 354.

3. Hamburger, M., and Hostettmann, K. Bioactivity in plants: the link between phytochemistry and medicine. Phytochemistry. 1991; 30: 3864 - 3874.

4. World Health Organization. Traditional Medicine: Growing Needs and Potential, WHO Policy Perspectives on Medicines. 2002: 1-6.

5. Sofowora, A. Medicinal plant and traditional medicine in Africa. Published in Association with Spectrum Books Limited Ibadan, John Wiley and Sons, Chinchester, New York. 1982: 66-91.

6. Ghasi, S., Nwobodo E., and Ofili, J. O. Hypocholesterolemic effect of crude leaf of Moringa oleifera in high fat diet fed wistar rats. J Ethnopharmacol. 2000; 69: 21-25.

7. Rios, J. L., and Recios, M. C. Medicinal plants and antimicrobial activity. J Ethnopharmacol. 2005; 100: $80-84$

8. Lee, C. K., Kin, H., Moon, K. H., and Shun, K. H. Screening and isolation of antibiotic resistance inhibitors from herb materials resistance inhibition of volatile components of Korean aromatic herbs. Arch Pharmaceut Res. 1998; 21: 62-66.

9. Afolabi, C., Akinmoladun, E. O., Ibukun, I., Emmanuel, A., Obuotor E. M., and Farombi, E. O. Phytochemical constituent and antioxidant activity of extract from the leaves of Ocimum gratissimum. Scientific Research and Essay. 2001; 2 (5): 163166. 
10. Doughari, J. K., and Manzara, S. In vitro antibacterial activity of crude leaf extracts of Mangifera indica. Afri J Microbiol Res. 2008; 2: 6972

11. Mosango, D. M. Euphorbia heterophylla L. In: Schmelzer, G. H., and Gurib-Fakim, A. (Ed). Prota. 2008; 11 (1): 1 - 2.

12. Okeniyi, S. O., Adedoyin, B. J., and Garba, S. Phytochemical Screening, Cytotoxicity, Antioxidant and Antimicrobial Activities of stem and leave extracts of Euphorbia heterophylla. Bull Environ Pharmacol Life Sci. 2012; 1 (8): 87-91.

13. Erden, Y. S., Ekrem, H., Gisho, T., and Yoshiohiro, T. Traditional medicine in Turkey IX, folk medicine in Northwest Anatolia. J Ethnopharmacol. 1999: 64: 201.

14. Falodun, A., Okunrobo, L. O., and Uzoamaka, N. Phytochemical screening and anti- inflammatory evaluation of methanolic and aqueous extracts of Euphorbia heterophylla Linn (Euphorbiaceae). Afr J Biotechnol. 2006; 5 (6): 529- 531.

15. Unekwe, P. C., Ughachukwu, P. O., and Ogamba, J. O. Some pharmacological Studies of Aqueous extract of leaves of Euphorbia heterophylla. Trop ] Med Resources. 2006; 10 (2): 1-5.

16. Djekota, C., Diouf, D., Sane, S., Mbaye, M., and Noba, K. Morphological characterization of shea tree (Vitellaria paradoxa) populations in the region of mandoul in Chad. Int J Biodivers Conserv. 2014; 6 (2): 184-193.

17. Orwa, C., Mutua, A., Kindt, R., Jamnadass, R., and Simons, A. Agroforestree Database: a tree reference and selection guide version 4.0. 2009: 1-10.

18. Fobil, J. N., Abbiw, D. K., Attuquayefio, D. K., and Adomako, E. Case study: Shea butter in Ghana. 2002; Retrieved February 3 ${ }^{\text {rd }}, 2014$.

http://www.sheabutterr-naturcreme.de/index.php? content $=1$

19. Murray, P. R. Enterobacteriaceae. Medical Microbiology. Farrell, R. (Ed.). Mosby Year Book Inc., London, UK. 1994: 227-240,

20. AL_Ouqaili, M. T. S. The Enteric Bacteria. A PhD thesis presented at Cairo University.2013: 1-10.

21. Iyamabo, P. A. Thesis on comparative antimicrobial activity of crude extract of Terminalia macroptae with phenol chlorhexidine and gentamycin. Pharmacognosy J. 1991; 1 (1): 12.

22. Harborne, J. B. Phytochemical methods; A guide to modern techniques of plant analysis. $2^{\text {nd }}$ edition, London, Chapman and Hall, London. 1984:1-19, 37-168.

23. Trease, G. E., and Evans, W. C. A Text Book of Pharmacognosy. EL SB/Bailliere Tindal, Oxford, UK 1984: 1055.

24. Idu, M., and Igekele, C. L. Antimicrobial activity and phytochemistry of Khaya senegalensis root. Int J Ayurvedic Herb Med. 2012; 2 (3): 416-422.

25. Canadian Council on Animal Care (CCAC). Guidelines on animal use protocol review. 1997: 1-5.

26. Eman, M. A., and Hoda, M. Z. Studies on the effect of garlic preparation on Escherichia coli O157:H7 causing enteritis in lambs. Egyptian J Clin Pathol. 2008; 21 (4): 102-129.

27. Itelima, J. U., and Agina, S. E. In vivo antimicrobial activity of plant species on Escherichia coli 0157: $\mathrm{H7}$ inoculated into albino rats. World J Microbiol. 2014; 1 (1): 2-9.

28. Oyedum, M. U. Phytochemical Screening, In vitro and in vivo activity of extracts of parts of Vitellaria paradoxa against $S$. typhi and $S$. flexneri. An unpublished MTech thesis, Federal University of Technology, Minna, Niger State, Nigeria. 2015: 5659.

29. Onwuliri, F. C. Antimicrobial studies of the extracts of Acalypha wilkesiana $\mathrm{L}$. on microorganisms associated with wound and skin infections. West Afr J Biol Sci. 2004; 15: 15-19.

30. Sofowora, A. Medicinal plant and traditional medicine in Africa. Published in Association with Spectrum Books Limited Ibadan, by John Wiley and Sons, Chinchester, New York. 1982; 66-91.

31. Mensah, J. K., Okoli, R. I., Ohaju-Obodo, J. O. and Eifediyi, K. Phytochemical, nutritional and medical properties of some leafy vegetables consumed by Edo people of Nigeria. Afr J Biotechnol. 2008; 7: 2304-2309.

32. Edeoga, H. O., Okwu, D. E., and Mbaebie, B. O. Phytochemical constituents of some Nigerian medicinal plants. Afr J Biotechnol. 2005; 4: 685688.

33. Egunyomi, A., Moody, J. O., Eletu, O. M. Antisickling activities of two ethnomedicinal plant recipes used for the management of sickle cell anaemia in Ibadan Nigeria. Afr J Biotechnol. 2009; 8: 20-25.

34. Schneider, G., and Wolfhing, J. Sherries Medical Microbiology. An Introduction to Infectious Disease. $4^{\text {th }}$ ed. 2004: 261-273.

35. Calixto, H. Effect of geographical location on antibacterial activity. 2000. Retrieved February $3^{\text {rd }}$, 2014. http://www.sheabutterr-naturcreme.de/index. php?content $=1$

36. Rhiouani, H. R., Nazari, P., Kamli-Nejad, M., and Lyoussi, B. Acute and sub-chronic oral toxicity of an aqueous extract of leaves of Herniaria glabra in rodents. J Ethnopharmacol. 2008; 118: 378 -386.

37. Pillai, P. G., Suresh, P., Mishra, G., and Annapurna, M. Evaluation of the acute and subacute toxicity of the methanolic leaf extract of Plectranthus amboinicus (Lour) Spreng in Balb C mice. Euro J Exp Biol. 2011; 1 (3): 236-245. 